\title{
Muting the Trumpets of Sabotage: Saudi Arabia, the US and the Quest to Securitize $\operatorname{Iran}^{1}$
}

Dr Simon Mabon s.mabon@lancaster.ac.uk

In recent years, the rivalry between Saudi Arabia and Iran has become increasingly influential in shaping the nature of Middle Eastern politics, with the two exerting influence across the region in an attempt to increase their power and to reduce that of the other. Amidst an increasingly fractious region, this article explores Saudi Arabia's attempts to securitize Iran to actors in the US. The signing of the nuclear agreement and the failure of the US to move beyond normal politics signals the failure of Riyadh's efforts to securitize Iran. Understanding the nature of relationships in the region, particularly between Riyadh and Tehran and between Riyadh and Washington, helps to understand the changing nature of regional politics and ultimately, the emergence of a more pro-active Saudi foreign policy.

Words: 10409

${ }^{1}$ I would like to thank Dr Sarah Hitchen for her insightful comments on an earlier draft of this article. 


\section{Introduction}

In recent years, the rivalry between Saudi Arabia and Iran has become increasingly influential in shaping the nature of Middle Eastern politics, with the two exerting influence across the region in an attempt to increase their power and to reduce that of the other. Following the execution of the Shi'a cleric Sheikh Nimr al-Nimr on the $2^{\text {nd }}$ January 2016, relations between Saudi Arabia and Iran became increasingly fractious, resulting in the storming of the Saudi embassy in Tehran and the severing of diplomatic ties between the two. For decades, the two have been engaged in the construction of security both internally and externally, which has regularly spilled out across the region. One of the primary areas of tension within the rivalry is over differing views of the organisation of regional security within the Persian Gulf: For Iran, those within the Gulf regional security complex should maintain security and stability, yet for Saudi Arabia the US is integral in shaping Gulf security. The signing of a nuclear deal between Iran and the P5+1 and the easing of sanctions on the Iranian economy has only served to fuel tensions between Tehran and Riyadh. The nuclear deal would alter Gulf regional security calculations, causing consternation in Riyadh about a thaw in relations between the US and Iran along with concern that the US may withdraw from the Gulf. Given these concerns, Saudi Arabia sought to securitize the Iranian threat to an American audience to prevent further rapprochement between Tehran and Washington.

With the emergence of a new administration in Washington, the legacy of such efforts may facilitate a new trajectory of US foreign policy. To understand the nature of such a policy, exploring Saudi Arabian efforts to shape US foreign policy, particularly towards Iran, is imperative. Although the majority of these efforts to securitize the Iranian threat occurred under previous administrations, they have created conditions that will impact upon the current administration's policy, both towards Saudi Arabia and Iran. Whilst the paper argues that securitization efforts were largely unsuccessful, such efforts have replicated - and indeed contributed to the facilitating conditions, which can impact upon foreign policy decisions. Relations between Riyadh and Washington became increasingly fractious under the Obama administration, but in the early stages of the Trump presidency, there is optimism that the relationship will improve. One reason for such optimism is that the Trump administration has vociferously condemned the Iranian nuclear deal, which may, in part, stem from Saudi and Israeli efforts to securitize the Iranian nuclear threat. What also should be acknowledged is that the Israeli administration of Benjamin Netanyahu has also sought to securitize the Iranian threat, however, this paper will focus predominantly upon Riyadh's efforts, in order to contribute to understandings of the rivalry between Saudi Arabia and Iran and, ultimately, Gulf security calculations. Ultimately, the change in administration, coupled with the atmosphere created by failed securitization efforts leads to the possibility that future attempts will be more successful in ending 'normal politics'.

Of course, Saudi security policies are not restricted to Iran and also include Da'ish, fragmentation of Yemen, increasing influence of GCC states, domestic instability, societal security, economic challenges, environmental problems and dynastic 
competition within the Al Saud. The Iranian threat, however, is of paramount concern to Riyadh, given the importance of religion to the Al Saud amidst claims of being the protectors of the two holy places. Moreover, Tehran's ability to shape events in neighbouring states and across the region broadly, means that Riyadh is increasingly concerned as to Iranian aspirations. To this end, this article focuses upon Iran within Saudi Arabia's security calculations.

Post 2011, the use of sectarian narratives - often couched in anti-Iranian terms became increasingly popular across Middle Eastern states ${ }^{2}$ in an attempt to maintain control over increasingly turbulent populations. Despite this, sectarian differences are not inherently violent and need not result in violence. In recent years, use of the term has contained assumptions about othering and suspicion, ${ }^{3}$ stemming from, as Ismael and Ismael argue, the "generation of animus and feelings of exclusion between individuals and groups on the basis of attaching negative meaning to group traits". 4

A burgeoning academic literature on sectarianism exists, suggesting that rulers have sought to use sectarian identities in an attempt to further regime interests. ${ }^{5}$ In the aftermath of the uprisings a number of people have engaged with the idea of sectarianism in the Gulf. Frederick Wehrey, Lawrence Potter, and Toby Matthiessen have all explored the construction of sectarian differences as a mechanism of control of domestic unrest, ${ }^{6}$ yet the securitization of sectarianism can also be conducted for external audiences, reflecting broader geopolitical concerns. The religious composition of Middle Eastern states - which are predominantly Sunni - mean that Shi'a and Iranian identities have often been securitized as a means of ensuring control and survival.

To understand contemporary Middle Eastern politics and Riyadh's efforts to speak to the US, it is necessary to engage with the rivalry between Saudi Arabia and Iran. The state building process of many states in the Middle East, stemming from a legacy of colonialism, conflict and porous borders, has left a number of regimes attempting to increase their legitimacy and ensure their survival. Given the importance of Islam as a tool of legitimacy - for both domestic and external audiences - regimes have often

\footnotetext{
${ }^{2}$ Helle Malmvig, 'Power, Identity and Securitization in Middle East: Regionla Order after the Arab Uprisings', Mediterranean Politics 19:1 (2014) p146.

${ }^{3}$ Fanar Haddad, 'Sectarian Relations in Arab Iraq: Contextualising the Civil War of 20062007', British Journal of Middle Eastern Studies, 40:2 (2013) p118

${ }^{4}$ Jacqueline S. Ismael, and Tareq Y. Ismael, 'The sectarian state in Iraq and the new political class', International Journal of Contemporary Iraqi Studies, 4:3 (2010) p340

${ }^{5}$ See: Fred Halliday, The Middle East in International Relations (Cambridge: Cambridge University Press, 2005); self-citation.

${ }^{6}$ See: Frederic M. Wehrey, Sectarian Politics in the Gulf: From the Iraq War to the Arab Uprisings (Columbia: Columbia University Press, 2014); Lawrence Potter (ed) Sectarian Politics in the Persian Gulf (London: Hurst, 2014); and Toby Matthiessen Sectarian Gulf: Bahrain, Saudi Arabia and the arab Spring that Wasn't (Stanford: Stanford University Press, 2013)
} 
employed Islamic rhetoric and laid claim to leadership over the $u_{m m a}{ }^{7}$ in an attempt to increase the legitimacy of their regime, which often results in an increase in tensions across the region. Tensions emerge from the belief that Islamic legitimacy is often seen in zero-sum terms, where an increase in one state's Islamic legitimacy is perceived to coincide with a decrease in another's legitimacy.

Efforts to understand the rivalry between Riyadh and Tehran have produced a body of literature that can be separated into three camps. The first suggests that the rivalry is best understood through a balance of power in the Gulf. ${ }^{8}$ This position suggests that states compete over regional hegemony in a range of different arenas and when sovereignty fragments, the opportunity to increase power emerges. The second camp ${ }^{9}$ suggests that religion plays a prominent role in shaping the nature of the rivalry and that proxy conflicts have been drawn along sectarian lines. It boils the rivalry down to an existential struggle about religious difference, neglecting the complexity of identity construction - and change - or the political ramifications of identity politics. The third camp suggests that a more nuanced approach is needed, drawing upon concerns about regime power and legitimacy - externally and internally - with the instrumentalised use of religious difference. ${ }^{10}$ It quickly becomes apparent that religion plays an important role within the fabric of both states but that there are regional repercussions of the instrumental use of religious rhetoric for domestic audiences. Moreover, that given the ethno-religious complexity of the Middle East, the treatment and fates of sectarian kin can leave the region open to external interference. As such, the use of Islam serves not only to legitimise rulers but also provides scope to increase power and influence across the region. From this, separating religion from understandings of power and security is infelicitous and damaging when considering the nature of contemporary Middle Eastern politics.

The idea of an existential threat is of paramount importance when considering the process of securitization. At the centre of such threats are questions about being, of continuation, and ultimately of survival. These challenges can occur in a range of different guises, from different locations, internally and externally, and can be seen as a threat to a regime or a state. Of course, such threats and challenges are subjective, yet find traction within the context of a regional security complex - a region that shares a number of similar security concerns - amidst shared normative environments, particularly when religion is used instrumentally. The prominence of conflict - defined broadly - gives the regional security complex a particular

\footnotetext{
${ }^{7}$ See: Fred Halliday, 'The Politics of the Umma', Mediterranean Politics 7:3 (2002).

${ }^{8}$ Such as: Henner Furtig, Iran's Rivalry with Saudi Arabia Between the Gulf Wars (Reading: Ithaca Press, 2006); Shahram Chubin and Charles Tripp, Iran-Saudi Arabia Relations and Regional Order (London: OUP for IISS, 1996), Banafsheh Keynoush, Saudi Arabia and Iran: Friends or Foes? (London: Palgrave, 2016) and Robert Mason, Foreign Policy in Iran and Saudi Arabia: Economics and Diplomacy in the Middle East (London: I.B. Tauris, 2014)

${ }^{9}$ Such as Vali Nasr, The Shia Revival: How Conflicts within Islam will Shape the Future (New York: W.W. Norton, 2007), and Augustus Richard Norton,

${ }^{10}$ Self-citation and Lawrence Rubin, Islam in the Balance: Ideational Threats in Arab Politics (Stanford: Stanford Security Studies, 2014),
} 
character, which has imbued states across the region with myriad security calculations at different levels of analysis. Although interdependent, efforts to resolve particular security challenges have wider repercussions for the regional security environment and, conversely, the weakness of regimes in the region means that challenges in one can result in the emergence of security issues across the region. Of course, this approach is couched in military-political approaches of security with the state as the referent object. For the purpose of our project we must consider how ideological (religious) and societal security shapes interactions between actors., moving beyond state-state understandings of international relations.

One of the main areas of tension across the Gulf is over the role of the US within the region. For Saudi Arabia, the US has long played an integral role in ensuring regional security, but for Iran, regional security calculations should be left to those within the Gulf. In recent years, Riyadh's relationship with Washington has become increasingly fractious, stemming from Washington's failure to respond to attempts to securitize Iran, the signing of the nuclear agreement between Iran and the P5+1, and recent claims about Saudi involvement in 9/11. Amidst these changing dynamics, this article explores how Saudi Arabia has attempted to securitize Iran to actors in the US. While most securitization approaches seek to do so within the territorial borders of a state, the moves within this process are trans-border, involving three states and state action in a further 5. It has also involved other actors contributing to Riyadh's securitizing moves, amidst shared concerns at Iranian interference across the region. Saudi securitization efforts run alongside - yet independent of - Israeli efforts to securitize Iran, whilst also building upon decades of US suspicion towards the Islamic Republic.

The article seeks to do two things: first it sets out the process of securitisation, building upon literature within the Copenhagen School. Within this process - and given the complexity of relationships - concepts of the audience and facilitating conditions are important to understand regional politics. Second, it explores SaudiIranian relations post 1979 looking at the reasons for - and processes of securitising the Iranian threat to the US audience. The signing of the nuclear agreement and the failure of the US to move beyond normal politics signals the failure of Riyadh's efforts to securitize Iran. Understanding the nature of relationships in the region, between Riyadh and Tehran and between Riyadh and Washington, helps to understand the changing nature of regional politics and ultimately, the emergence of a more pro-active Saudi foreign policy. In order to do this, I draw upon interviews conducted in Bahrain and the UK, with a range of policy makers and citizens of Gulf countries. I have supplemented this with US diplomatic cables released by the Wikileaks organisation. Whilst problematic, the cables provide an important insight into the inner workings of diplomatic processes, which proves essential when considering the nature of Saudi Arabia's securitization efforts to an American audience. 


\section{Securitization and the Copenhagen School}

The Copenhagen School provides an analytical framework through which to engage with the process of securitization, broadly understood as the move beyond 'normal politics' to eradicate a threat. The school, driven by the work of Barry Buzan and Ole Wæver, frames the securitisation of a range of different issues through the use of language, taking the issue beyond 'normal politics' through the use of a 'speech act'. ${ }^{11}$ As Thierry Balzacq suggests, "the enunciation of security itself creates a new social order wherein 'normal politics' is bracketed". ${ }^{12}$ Reflecting a growing concern within Security Studies about broadening the agenda, the Copenhagen School seeks to move the referent object of security away from the state and onto a range of other issues.

In the process of securitization, an actor frames an issue as a serious threat to the security of a particular audience, claiming "a need for and a right to treat it by extraordinary means". ${ }^{13}$ Not all speech acts are successful acts of securitization - as we shall come to see - suggesting that the audiences may not always be convinced of the existential nature of the threat or of the need for the extra-ordinary measures demanded by the securitizer. As Paul Roe notes, the deployment of emergency measures is not a necessary condition of success. Indeed, for Roe, while audiences may accept the 'frame', they may also choose to reject the implications for securitization. ${ }^{14}$ From this, it is necessary to explore the conditions that facilitated the securitization process.

Speech acts do not occur in a vacuum, yet engagement with the social and political context within which the acts occur lack adequate exploration. ${ }^{15}$ Matt McDonald suggests that what little engagement is given to the context of the act occurs across three areas. The first is the designation of threat, with the sector in which the securitization occurs shaping the type of designation that emerges. The second is the facilitating conditions, namely the dynamics that allow for such a move to find traction. For Wæver, this is understood as the "conditions historically associated with that threat" ${ }^{16}$ and combined with the form of the speech act and the role of the securitizing actor. The third is the audience, towards whom the speech act attempts to securitize an issue. The audience for a particular speech act depends upon the

\footnotetext{
${ }^{11}$ John L. Austin, How to do Things with Words, (Oxford: Oxford University Press, 1962).

${ }^{12}$ Thierry Balzacq, 'The Three Faces of Securitization: Political Agency, Audience and Context', European Journal of International Relations 11:2 (2005), p171.

${ }^{13}$ Barry Buzan, Ole Wæver and Jaap de Wilde, Security: A New Framework for Analysis (Boulder, CO: Lynne Rienner, 1998), p26.

${ }^{14}$ Paul Roe, 'Actor, Audience(s) and Emergency Measures: Securitization and the UK's Decision to Invade Iraq', Security Dialogue 39:6 (2008), p621.

${ }^{15}$ Matt McDonald, 'Securitization and the Construction of Security', European Journal of International Relations 14:4 (2008) pp570-1.

${ }^{16}$ Ole Wæver, 'The EU as a Security Actor: Reflections from a Pessimistic Constructivist on Post-Sovereign Security Orders', in Morten Kelstrup and Michael C. Williams (eds) International Relations Theory and the Politics of European Integration: Power, Security and Community (London: Routledge, 2000). pp252-3.
} 
nature of the particular threat, along with the type of response that the securitizer is seeking. Balzacq asserts that the conditions within which the context is formed is comprised of the domestic and the international levels and it is the latter that our study will focus upon. ${ }^{17}$ Moreover, it is the latter that the process of securitization will be for, insomuch as the process of securitization engages with power relations and for Saudi Arabia, security is determined with the US in mind as a guarantor.

Questions must then be asked as to the location of the threat, moreover, at which level of analysis the process of securitization takes place. ${ }^{18}$ In much of the recent work, the regional level has gained prominence, yet clearly what happens regionally with regard to the securitization of a threat will also have domestic consequences and, given the nature of political organisation across the Middle East, vice versa. Additionally problematic is the notion that by focussing upon the regional security complex, Realist ideas are brought back into the analysis through the assumption that states are the main building blocks of a region, disregarding other prominent factors. This article highlights that such problems are not insurmountable.

By undertaking such analysis, questions about the location of an audience must be addressed, which may challenge the linear process of securitization that dominates the literature. Additionally, questions must also be raised as to the nature of 'normal politics', exceptional measures and desecuritization at the international level. Moreover, we should also consider the problems of applying such a framework to the non-Western world. Caught up in what has been termed the 'Westphalian straitjacket' are a number of assumptions about the nature of sovereignty, of societal organisation and the context within which securitization occurs. Indeed, a range of problems that challenge Westpahlian assumptions are, as Claire Wilkinson suggests, "conveniently overlooked at best, and at worst reinterpreted or 'edited out $^{\prime \prime 19}$ in an attempt to stress the linear assumptions about how securitization is constructed. Wilkinson also stresses that the 'Westphalian straitjacket' means that "security dynamics are edited and Westernized through the application of the theoretical framework", ${ }^{20}$ ignoring the nature and organisation of society in the nonWestern world, where identities - and indeed the securitized threat - can transcend state borders. Indeed, while identity is linked to the state, the steady concepts at the heart of the securitization process risk essentialising identities.

Yet as Wæver acknowledges, introducing facilitating conditions can also reintroduce objectivism into securitization, albeit an interpretation that he rejects, ${ }^{21}$ as this external context must refer to an objective or material character in order for $X$ to be

\footnotetext{
${ }^{17}$ Balzac, (2005), 183.

${ }^{18}$ Buzan, Barry \& Ole Wæver, 2003. Regions and Powers. (Cambridge: Cambridge University Press, 2003) p13

${ }^{19}$ Claire Wilkinson, 'The Copenhagen School on Tour in Kyrgyzstan: Is Securitization Theory Useable Outside Europe?' Security Dialogue 38:1 (2007) p21

${ }^{20}$ Wilkinson, (2007), p22.

${ }^{21}$ Ole Wæver, 'Reflections from a Pessimistic Constructivist on Post-sovereign Security Orders', in International Relations Theory and the Politics of European Integration, eds Morten Kelstrup and Michael Williams (London: Routledge, 2000). p252.
} 
threatening and to constitute a security threat. It is possible, however, to circumvent this challenge by rejecting the conventional security studies assumption that 'security exists out there independently of our putting it into security terminology'22. Instead it is possible to refer to a 'pre-existing body of socially constructed knowledge that provides meaning to the presence of an object" ${ }^{23}$ Balzacq suggests that external context should be associated with the 'psycho-cultural orientation' ${ }^{24}$ of the audience, which, when coupled with objective developments, existential threats can be accepted when an audience can "look around" and substantiate claims made by securitizing actors". ${ }^{25}$ As such, the Constructivism at the heart of securitization remains integral to the process and as such, it is important to consider the construction of the facilitating conditions, through referring to the construction of knowledge and narratives across history.

Empirical analysis of the process of securitization is typically limited to the realm of high politics - in the guise of the state - often excluding actors on the periphery, or sub-state actors. Indeed, securitization is largely limited to those officials, leaving other actors in the 'analytical shadows' ${ }^{26}$ Balzacq builds on this by stressing that particular actors are empowered to 'speak security' as a consequence of their access to the media, yet also by virtue of their access to audiences in other states. ${ }^{27}$ Yet it is possible to remove some of these challenges and incorporate a less linear concept of how the securitization process works by focussing the analysis on those processes involved in securitization instead of the process of securitization. ${ }^{28}$ Such focus is important when considering that at the diplomatic level it is imperative to consider that within agency, action may precede speech acts, albeit independent of such acts. Moreover, diplomatic relations precede speech acts and will continue in some form, regardless of efforts to securitize a particular threat.

One possible consequence of a failed effort at securitization is the breakdown of relations between the securitizer and the audience, particularly if the audience rejects the securitization process. Another potential pitfall is that additional audiences can be created - intentionally or unintentionally - through such an act. Clearly, linear processes of securitization are less applicable in cases where public or semi-public forms of securitization take place, where indirect audiences can be created with potentially serious ramifications. Moreover, when such a process takes place in the public or semi-public, there can be the securitization of the threat for unintended audiences. As such, given shared political and normative environments

\footnotetext{
${ }^{22}$ Wæver., (2000) p 251.

${ }^{23}$ Scott D. Watson, 'Framing' the Copenhagen School: Integrating the Literature on Threat Construction' Millennium (2012) 40(2) p295

${ }^{24}$ Balzacq, (2005), p174 and 181.

25 Wilkinson (2007), p294.

${ }^{26}$ Wilkinson, (2007), p15

${ }^{27}$ Balzacq,(2005)., p191

${ }^{28}$ Charlotta Wagnsson, Russian Political Language and Public Opinion on the West, Nato and Chechnya - Securitisation Theory Reconsidered. (Stockholm: Akademitryck AB, Edsbruk, 2000) pp17-19
} 
across the region, there could be regional consequences from such speech acts. To increase awareness of this it is imperative to feed in greater discussion of the facilitating conditions.

\section{The Roots of Securitization and Rhetorical Retribution: The Designation}

We must begin by considering the designation of the threat, which involves a challenge to the legitimacy of Saudi Arabia - and ultimately the Al Saud - as the protectors of the two holy places and the leaders of the Muslim world. In engaging with this, it is important to consider how - and why - Riyadh perceives Tehran to pose a threat that requires a process of securitization. It is with these considerations in mind that we are able to understand the conditions that give rise to securitization moves. To this end, it is important to offer a brief genealogy of the relationship between the two states from the revolution in 1979.

The current Saudi state, formed in 1932 has at its heart a centuries old alliance between the Al Saud and Wahhabi clerics. ${ }^{29}$ Post revolution, Saudi Arabia and Iran became increasingly embroiled in competition within the Islamic sphere and, as Shahram Chubin and Charles Tripp suggest, over "Islamic leadership". ${ }^{30}$ This resulted in a spiralling flux of rhetoric that sought to demonstrate the legitimacy and vitality of regimes in both Riyadh and Tehran often at the expense of the other. The new republic would write a constitution with Shi'ism at its heart theologically and politically. The narrative of the Battle of Karbala, in which Hossein was killed, would feature prominently, with ideas of guilt and responsibility playing an important role within the state's behaviour.

Khomeini's rhetoric included criticisms of several leaders across the Muslim world, notably the Al Saud, whom he regarded as "corrupt and unworthy to be the guardians of Mecca and Medina" ${ }^{31}$ while also referring to them as "traitors to the two holy shrines". ${ }^{32}$ Such disdain stemmed from a rejection of monarchy as an acceptable form of government within Islam, along with the perceived impropriety of the Al Saud. Khomeini's rhetoric was supported by an apparent incitement to riot on the 1987 Hajj, with pilgrims being urged to move from "holy Hajj to holy jihad by bathing yourselves in blood and martyrdom". ${ }^{33}$ Khomeini also sought to export his ideology internationally, while increasing Iran's legitimacy internationally, by opposing the West and also offering support to the mustazefin or downtrodden, of the Muslim world:

\footnotetext{
${ }^{29}$ David Commins, The Wahhabi Mission and Saudi Arabia (London: IB Tauris, 2006).

${ }^{30}$ Chubin and Tripp, (1996), p53.

${ }^{31}$ Con Coughlin, Khomeini's Ghost (London: Macmillan, 2009), p274.

${ }^{32}$ Excerpts from Khomeini's Speeches, (New York Times, 04.08.87) Available from: http://www.nytimes.com/1987/08/04/world/excerpts-from-khomeinispeeches.html?pagewanted=all\&src=pm accessed: $12.02 . .10$

${ }^{33}$ Jacob Goldberg, 'The Saudi Arabian Kingdom', in Rabinovich, Itovar., and Shaked, Haim., (eds.) Middle East Contemporary Survey Volume XI: 1987 (Boulder: Westview Press, 1987), p589.
} 
We will export our experiences to the whole world and present the outcome of our struggles against tyrants to those who are struggling along the path of God, without expecting the slightest reward. The result of this exportation will certainly result in the blooming of the buds of victory and independence and in the implementation of Islamic teachings among the enslaved nations. ${ }^{34}$

Khomeini's words elucidate the ideological roots of Iranian support for organisations across the Middle East such as Hizballah, Hizballah al-Hijaz in Saudi Arabia's Eastern Province, and Shi'a minorities across the region, which became enshrined in the constitution. Ultimately, support for Shi'a minorities and the mustazefin across the Middle East would challenge the regional status quo. The onset of conflict with Iraq in 1980 would fuel Riyadh's concerns at Iranian aspirations across the region, along with the perception that the Shi'a of Iraq would side with their sectarian kin. Despite this, loyalty to the state trumped sectarian loyalties, perhaps as a consequence of a legacy of Arab-Persian tensions.

While Iran initially sought to downplay sectarian tensions, the Al Saud stressed these differences, regularly employing anti-Shi'a rhetoric - which proved to incense both Iran and its own Shi' a population - in an effort to placate the more hard-line clerics and its population. In the immediate aftermath of the events of 1979 , several clerics in Saudi Arabia issued fatwas against Shi'a Muslims, including denouncing the Shi'a as apostates and sanctioning the killing of members of the Shi'a community. ${ }^{35}$ These tensions, although couched in theological terms, possess a clear political aspect, seeking to erode the legitimacy of the other. From this, it is easy to see how religion has played an important role in shaping the nature of the rivalry, with the need to speak to domestic audiences having an impact upon external relations and external relations impacting upon domestic stability. Religion continues to play a prominent role in shaping the nature of the rivalry, with Ayatollah Ali Khamenei predicting "divine vengeance" for the execution of Sheikh Nimr. ${ }^{36}$ Additionally, the official website of the Supreme Leader posted a cartoon that sought to draw parallels between the Al Saud regime and Da'ish. ${ }^{37}$

The consequences of the revolution in Iran would be felt in Bahrain and the Eastern Province in Saudi Arabia, albeit in different contexts, demonstrating the ramifications of political change in Iran along with the rising importance of Islam across the region. In Bahrain, the Islamic Front for the Liberation of Bahrain (IFLB) attempted a coup d'etat with support from the IRGC Qods Force. ${ }^{38}$ While the coup failed, the legacy of it continues to this day, with Iranian involvement creating the

\footnotetext{
${ }^{34}$ New York Times, (1987).

${ }^{35}$ Nasr, (2007), p236.

${ }^{36}$ Ali Fathollah-Nejad, Iran and Saudi Arabia: The Impending Storm (Qantara.de, -06.01.16)

Available from: https://en.qantara.de/content/iran-and-saudi-arabia-the-impending-storm accessed 07.01.16

${ }^{37}$ Any differences? (Khamenei.IR, 02.01.16) Available from: http://english.khamenei.ir/news/3018/Any-differences accessed 06.01.16

${ }^{38}$ Hasan Alhassan, 'The Role of Iran in the Failed Coup of 1981: The IFLB in Bahrain', The Middle East Journal 65:4 (2011)
} 
perception that Iranian agents are behind unrest across the archipelago. ${ }^{39}$ These events also resulted in the building of the King Fahd Causeway, linking Bahrain to the Eastern Province of Saudi Arabia, designed to allow easy access to the archipelago should the situation arise. ${ }^{40}$ In Saudi Arabia, the revolution in Iran would inspire a period of unrest in the Shi'a dominated Eastern Province. While many in Bahrain, Saudi Arabia and the West believed that Iranian agents were behind this unrest, evidence to support such claims is largely absent. ${ }^{41}$

The alliance with Wahhabism is integral for the Al Saud's stability and any reference to leadership within the Islamic world is viewed as an attempt to undermine their position. Riyadh's response sought to reduce the appeal of the revolution in Iran to Sunni Muslims by stressing the Shi'a nature of the revolution and reiterating the incompatibility of Shi'a and Sunni (Wahhabi) thought, attempting to prevent the emergence of a united Islamic community. Moreover, the Al Saudi sought to frame the revolution as another instance of Iranian expansionism. ${ }^{42}$ In a speech prior to the Hajj of 1987, Fahd attacked the "hypocrites and pretenders who are using Islam to undermine and destabilise other countries". ${ }^{43}$

Efforts to use Islam for political purposes is also seen in the securitization of Islamic solidarity, demonstrated by the increase in funding from Saudi Arabia to Islamist groups across the world from the 1970 s onwards. ${ }^{44}$ The Organisation of Islamic Cooperation (OIC) was also politicized: In early 2016, the OIC denounced "Iran's interference in the internal affairs of the States of the region and other Member States (including Bahrain, Yemen and Syria and Somalia) and its continued support for terrorism". ${ }^{45}$ The importance of Islam within Saudi Arabia meant that Iran's behaviour on the international stage was a cause of great consternation in Riyadh and required a range of different strategies in response.

\section{Political Fragmentation and 'Fifth Columns': The Facilitating Conditions}

The second stage of the securitization process is to consider the facilitating conditions within which the process can find traction and an issue can be securitized. Following the 2003 invasion of Iraq, relations between Riyadh and Tehran would deteriorate, in part as a consequence of the election of Mahmoud Ahmadinejad in

\footnotetext{
${ }^{39}$ Interview with Sunni Bahraini businessman in Manama, 2013.

${ }^{40}$ Self citation

${ }^{41}$ Interviews with British officials in Manama, 2013.

${ }^{42}$ Henner Furtig, Iran's rivalry with Saudi Arabia between the Gulf Wars (Reading: Ithaca Press, 2002), p219.

${ }^{43}$ Goldberg, (1987), p589.

${ }^{44}$ Thomas Hegghammer, Jihad in Saudi Arabia: Violence and Pan-Islamism since 1979 (Cambridge: Cambridge University Press, 2011) p21.

${ }^{45}$ Final Communique of The Extraordinary Meeting of The Council of Foreign Ministers of The Organization Of Islamic Cooperation on Aggressions on The Embassy of The Kingdom of Saudi Arabia in Tehran and Its Consulate General In Mashhad (Ogranisation of Islamic Cooperation, 22.01.16) Available from: http://www.oicoci.org/oicv2/topic/?t id=10837\&t ref=4262\&lan=en accessed 22.01.16
} 
2005. Political fragmentation across the Middle East provided scope for Riyadh and Tehran to engage in a series of proxy conflicts across the region, manipulating sectarian schisms in an attempt to increase geopolitical influence. Following the invasion of Iraq in 2003 and the onset of the Arab Uprisings in 2011, relations between regime and society fragmented and where those societies were divided along sectarian lines, proxy conflicts began to emerge as Riyadh and Tehran supported co-religionists to further their interests. These two sets of events, while fundamentally different, result in the fragmentation of states and it is within the context of fragmenting sovereignty and fracturing territoriality that space for the manipulation of domestic affairs by external actors is created. This space then becomes contested as actors vie for influence.

In the aftermath of the revolution, a great deal of suspicion arose as to the loyalties of Shi'a populations across the region, perhaps best characterised by King Abdullah of Jordan, who referred to a 'Shi'a Crescent', ${ }^{46}$ implicitly suggesting that Shi'a populations were fifth columns under the control of Tehran. Such comments fail to take into account the complex nature of identity politics across many Middle Eastern states, where identities are not binary. Although a number of states were affected by the uprisings, demographic factors in Bahrain, Syria and Yemen meant that they presented the best opportunity for Riyadh and Tehran to exert influence. Moreover, certain sites of proxy competition were seen as an extension of a state's sovereign territory, perhaps best highlighted by the case of Bahrain and the claims made by both Riyadh and Tehran over the sovereignty of the archipelago. ${ }^{47}$ The emergence of proxy conflicts in these three states would supplement proxy conflicts already taking place in Lebanon and Iraq.

Following the 2003 invasion, the fragmentation of Iraq and dismantling of the Ba'ath party infrastructure provided opportunity for Iran to increase power and influence through support for Shi'a militias. The establishment of a Shi'a-led government would be a cause of consternation for Sunnis in Iraq, along with Saudi Arabia, who feared the establishment of a Shi'a state along its northern border.

Within the context of these proxy conflicts, officials in Riyadh sought to frame the Iranian threat to US audiences. For many, Tehran's involvement in Iraq posed serious challenges to the sovereignty, stability and security of the Iraqi state. Reflecting this concern Prince Nayif bin Abdul Aziz stressed the importance of the US presence in Iraq, urging the US not to "leave Iraq until its sovereignty has been restored,

\footnotetext{
${ }^{46}$ Hardball with Chris Matthews: King Abdullah Il of Jordan. NBC News. 7 December 2008. Event occurs at 02:06 See also 06RIYADH3312 The Saudi Shi'a: Where do their loyalties lie? (02.05.06) Available from: https://wikileaks.org/plusd/cables/06RIYADH3312 a.html accessed 10.06.15.

${ }^{47}$ Self citation.
} 
otherwise it will be vulnerable to the Iranians'". ${ }^{48}$ The extent of Iran's penetration of Iraq at this time can be seen with the reference to the "Iranian City of Basrah" ${ }^{49}$

In 2009, White House counter-terrorism advisor John Brennan met King Abdullah. During the course of the conversation Abdullah expressed his concern about Maliki

The King said he had "no confidence whatsoever in (Iraqi PM) Maliki, and the Ambassador (Fraker) is well aware of my views". [...] For this reason, the King said, Maliki had no credibility. "I don't trust this man," the King stated, He's an Iranian agent." [...] Maliki has "opened the door for Iranian influence in Iraq" since taking power, the King said. 50

Such observations were commonplace. In a conversation between the Saudi ambassador to the US, Adel Al Jubeir and the Charge, Al Jubeir stressed the severity of the threat from Iran. Cable 08RIYADH649_a documents how Al Jubeir recalled

the King's frequent exhortations to the US to attack Iran and so put an end to its nuclear weapons program. "He told you to cut off the head of the snake," he recalled to the Charge', adding that working with the US to roll back Iranian influence in Iraq is a strategic priority for the King and his government. ${ }^{51}$

The cable also documented concern at the rising influence of Iranian militias across Iraq. ${ }^{52}$ During this time sectarian violence increased dramatically, resulting in the deaths of close to 200,000 civilians amidst fierce fighting between coalition forces, Al Qa'ida affiliates, government forces, tribes and Shi'a militias, a number of whom received support from Iran. ${ }^{53}$ Intra-sectarian fighting also took place, resulting in deep-seated rivalries between the Sadrist movement - Jaysh al-Mahdi (JAM) - led by Muqtada Al Sadr, and the Badr Brigades. Haider Al Abadi, then a senior Da'wa figure, drew comparison between the Sadrists and the Ba'athists, suggesting that in the long-term JAM posed more of a threat to non-Sadrist Shi'as than Al Qa'ida. ${ }^{54}$

\footnotetext{
${ }^{48}$ 06RIYADH9175_aSAUDI MOI HEAD SAYS IF U.S. LEAVES IRAQ, SAUDI ARABIA WILL STAND WITH SUNNIS (26.12.06) Available from: https://wikileaks.org/plusd/cables/06RIYADH9175 a.html ${ }^{49}$ 08BAGHDAD239_a "THE STREET IS STRONGER THAN PARLIAMENT:" SADRIST VOWS OPPOSITION TO LTSR (27.01.08) Available from: https://wikileaks.org/plusd/cables/08BAGHDAD239 a.html ${ }^{50}$ 09RIYADH447_aCOUNTERTERRORISM ADVISER BRENNAN'S MEETING WITH SAUDI KING ABDULLAH (22.03.14) Available from: https://wikileaks.org/plusd/cables/09RIYADH447 a.html ${ }^{51}$ 08RIYADH649_a SAUDI KING ABDULLAH AND SENIOR PRINCES ON SAUDI POLICY TOWARDS IRAQ (20.04.08) Available from: https://wikileaks.org/plusd/cables/08RIYADH649_a.html

${ }^{52}$ Self-citation.

${ }^{53}$ For an in depth discussion of the human cost of the fragmentation of the Iraqi state see: self citation.

${ }^{54}$ 07BAGHDAD3125_a DAWA LEGISLATOR: JAM IS "THE NEW BA'ATH," MORE DANGEROUS THAN AQI (17.09.07) Available from: https://wikileaks.org/plusd/cables/07BAGHDAD3125 a.html accessed 20.06.15.
} 
The outbreak of protests in Syria provided Saudi Arabia with an opportunity to alter regional dynamics and to "win Syria back to the Arab fold". ${ }^{55}$ Initially, this response was restrained, taking 3 months to publically criticise events in Syria as a consequence of the growing proximity between the Kingdom and the Assad regime. ${ }^{56}$ The state's increasingly violent response took place predominantly along sectarian lines and given Tehran's support for Assad, Riyadh was left with little option but to support the opposition. Prince Bandar Bin Sultan was then tasked with winning Syria, which he attempted to do by funding rebel groups. ${ }^{57}$

Across the arenas of proxy conflict, suspicions at the involvement of external actors were endemic. Concerns at Iranian penetration of Bahrain were rife, perhaps best expressed in the comment "the Persians are everywhere", ${ }^{58}$ also reflecting the longstanding suspicion of the Iranian 'other'. Despite sectarianism being constructed as the driving force of the conflict, the uprisings were grounded in socio-economic and nationalist conditions. Yet sectarian concerns were exacerbated by regular allegations of Iranian manipulation and the existence of Iranian supported bombmaking factories in Bahrain. ${ }^{59}$ Given the sectarian constitution of Bahrain, both $\mathrm{Al}$ Khalifa and Al Saud expressed concerns about the potential consequences of Shi'a empowerment across the archipelago and the region. ${ }^{60}$

Such concerns are long standing and in a diplomatic cable from 2006, King Hamad's concerns at Shi' a loyalties were revealed. For the King, "as long as Khamenei has the title of Commander-in-Chief, Bahrain must worry about the loyalty of Shia who maintain ties and allegiance to Iran". ${ }^{61}$ In an attempt to counter this, the Al Khalifa have offered passports to Sunnis from the Asian sub-continent on the condition that they serve in the police force for a set number of years. This serves two purposes: first, to alter the sectarian balance in favour of the Sunnis; second, police force numbers are bolstered by non-Bahrainis who would feel less affinity towards their nationalist kin and increasing security. ${ }^{62}$

\footnotetext{
${ }^{55}$ Madawi Al-Rasheed, The Saudi response to the 'Arab Spring': containment and co-option (Open Democracy, 10.01.12), Available from:

http://www.opendemocracy.net/5050/madawi-al-rasheed/saudi-response-to-

\%E2\%80\%98arab-spring\%E2\%80\%99-containment-and-co- option accessed 15.01.12.

${ }^{56}$ Hassan Hassan, Old Myths Perpetuate Poor Analysis of Saudi (The National, 17.01.16)

Available from: http://www.thenational.ae/opinion/comment/old-myths-perpetuate-pooranalysis-of-saudi accessed 18.01.16

${ }^{57}$ Mariam Karouny, Saudi edges Qatar to control Syrian rebel support (Reuters, 31.05.13)

Available from: http://www.reuters.com/article/us-syria-crisis-saudi-insightidUSBRE94U0ZV20130531 accessed 31.05.13. See also: Charles Lister, The Syrian Jihad: AlQaeda, the Islamic State and the Evolution of an Insurgency (London: Hurst, 2015).

58 Interview, Bahrain, May 2013.

59 Ibid.

${ }^{60}$ 6MANAMA873_a SCENESETTER FOR U.S.-BAHRAIN MILITARU CONSULTATIVE COMMITTEE, 23-24 MAY (18.05.06) Available from:

https://wikileaks.org/plusd/cables/06MANAMA873 a.html accessed 12.12.15

${ }^{61}$ 06MANAMA409_a LUNCHEON WITH KING HAMAD (15.03.06) Available from: https://wikileaks.org/plusd/cables/06MANAMA409 a.html accessed 16.12.15

${ }^{62}$ Interview with British official in Bahrain, 2013.
} 
The importance of identity within Bahrain should not be ignored. In the early stages of the uprisings, protesters were quick to state that this was a protest about political reform, not about sectarianism. In the coming months, the conflict would be framed as such, allowing the regime to solidify its position. From this, many Bahrainis have sought to suppress their religion or ties to Iran. ${ }^{63}$ Others continue to reject the construction of identities along sectarian lines, with one interviewee refusing to state his sectarian allegiance, instead stating "I'm just Bahraini" ${ }^{64}$

Perceptions of Iranian manipulation are not limited to Bahrain, with suggestion that Iran was supporting the Houthis ${ }^{65}$ in their war against the Yemeni army and the Saudi supported President Abel Hadi. ${ }^{66}$ Post uprisings, the Houthis gained much popularity and influence across the state, seizing Sanaa in 2014. A cable from 2009 noted that despite the perception of Iranian involvement in Yemen, while "Tehran's shadow looms large" over events in the state, "its footprint is small". The cable continues, suggesting that "the only visible Iranian involvement remains the Iranian media's proxy battle with Saudi and Yemeni outlets over support for the Houthis" ${ }^{67}$

US investigations into weapons in Yemen found that many were purchased from either the black market or from Yemeni army officials. ${ }^{68}$ Yet in September 2015 Saudi forces announced the seizure of an arms shipment allegedly from Iran and destined for the Houthis. ${ }^{69}$ Further complicating the situation are allegations that Saudi Arabia has supported and fought alongside the Al Qa'ida franchise in Yemen, despite waging a bitter war with the group in the Kingdom across the 2000s. ${ }^{70}$ In understanding the alliance between the two, cable 09SANAA1628_a reports a Radio Tehran allegation that in a phone call between President Saleh and Abdullah, the

\footnotetext{
${ }^{63}$ Interview with a Shi'a Bahraini in Bahrain, 2013.

${ }^{64}$ Interview with a Bahraini student in Manchester, 2014.

${ }^{65}$ Charles Schmitz, 'The Huthi Ascent to Power', Middle East Institute (15.09.15) Available from: http://www.mei.edu/content/at/huthi-ascent-power accessed 17.09.15

${ }^{66}$ To frame the Houthis purely in sectarian terms is infelicitous, as the group has been able to cultivate support from a range of groups by positioning themselves against the increasingly corrupt elites.

${ }^{67}$ O9SANAA1662_a IRAN IN YEMEN: TEHRAN'S SHADOW LOOMS LARGE, BUT FOOTPRINT IS SMALL (C-NE9-01257) (12.09.09) Available from:

https://wikileaks.org/plusd/cables/09SANAA1662 a.html accessed 14.01.16

${ }^{68}$ 09SANAA2186_a WHO ARE THE HOUTHIS, PART TWO: HOW ARE THEY FIGHTING?

09.12.09 Available from: https://wikileaks.org/plusd/cables/09SANAA2186 a.html accessed 14.01.16

${ }^{69}$ Ahmed Al Omran and Asa Fitch, Saudi Coalition Seizes Iranian Boat Carrying Weapons to Yemen (The Wall Street Journal, 30.09.15) Available from: http://www.wsj.com/articles/saudi-coalition-seizes-iranian-boat-carrying-weapons-torebels-in-yemen-1443606304 accessed 30.09.15

${ }^{70}$ Yaroslav Trofimov, Is Al Qaeda Winning in Saudi-Iran Proxy War in Yemen? (The Wall Street Journal, 10.09.15) Available from: http://www.wsj.com/articles/is-al-qaeda-winningin-saudi-iran-proxy-war-in-yemen-1441877581 accessed 30.09.15
} 
Saudi King offered to "cover the cost of the offensive, to provide weapons and ammunition and to put an end to the Houthi movement no matter the cost." ${ }^{71}$

Hassan al Lawzi, the Yemini Information Minister suggested that such reporting showed who was financing the Houthis. State-run media outlets were also vocal in their condemnation of

the treachery of the Persian media ... (which) reveals the ugly face of the trumpets of sabotage outside Yemen's borders, imposing upon the Yemeni media the patriotic duty of confronting the Iranian misinformation machine and its support for subversive elements in Sa'ada. ${ }^{72}$

While such moves are typically the province of high politics, their ability to find traction amongst the general public suggests the existence of concerns at Iranian action and aspirations.

Although ostensibly identified as proxy conflicts, both Riyadh and Tehran became directly involved in a number of conflicts. In Syria, Iran acted in support of the statusquo and maintained their link to Hizballah in southern Lebanon, while Saudi Arabia sought to facilitate a change in the regional order. The onset of the Syrian civil war would also help foster the rise of Da'ish, the violent fundamentalist group led by Abu Bakr al-Baghdadi. The group was of great concern to both Tehran and Riyadh, yet in the fight against Da'ish, the two states were reluctant to co-ordinate, resulting in a mismanaged response. Moreover, for Saudi Arabia and other GCC states, the Assad regime and Shi'a militias were deemed to pose a greater threat to regional security than Da'ish.

Ties between Hizballah and Iran are well documented, ${ }^{73}$ as is the penetration of Lebanon's confessional system and the emergence of two political blocs, the March $8^{\text {th }}$ and March $14^{\text {th }}$ alliances, which drew together a range of internal and external actors. Following the 2006 war with Israel, a large part of southern Beirut - Hizballah heartland - was destroyed. To help rebuild the area, Iran pledged $\$ 120$ million but Saudi Arabia donated $\$ 1.2$ billion. ${ }^{74}$ In providing financial aid to a prominent Shi'a organization with close links to Iran, domestic audiences in Saudi Arabia were antagonized, yet the popularity of Hassan Nasrallah's Party of God meant that such a risk was deemed worthwhile. ${ }^{75}$ In the following years, Saudi concerns at an increasingly galvanized Hizballah along with the perception of Iranian manipulation across the region would prevent such activity from taking place again. In early February, Saudi Arabia and other GCC states banned their citizens from travelling to

\footnotetext{
${ }^{71}$ 09SANAA1628_a SA'ADA CONFLICT: A PROXY WAR OF WORDS BETWEEN IRAN, SAUDI

ARABIA (02.09.09) Available from: https://wikileaks.org/plusd/cables/09SANAA1628 a.html accessed 14.01 .16

${ }^{72}$ Yemen: Is Peace Possible? (Middle East Report No.167, 09.02.16) Available from: http://www.crisisgroup.org/ /media/Files/Middle\%20East\%20North\%20Africa/Iran\%20Gulf Yemen/167-yemen-is-peace-possible.pdf _accessed 10.02.16

${ }^{73}$ Self citation.
${ }^{74}$ Self citation.
${ }^{75}$ Self citation.
} 
Lebanon due to concerns about their safety and the Party of God was proscribed as a terrorist organization across the GCC.

Shortly after the protesters took to the streets of Bahrain, the GCC Peninsular Shield Force was mobilised and crossed the King Fahd Causeway to stabilise the regime. The extent of Saudi involvement in the suppression of protest movements is contested, ranging from suggestions that Saudi troops were responsible for much of the violence across Manama to allegations that the Saudis were only protecting oil refineries. ${ }^{76}$ In recently released emails, then Secretary of State Hilary Clinton was informed that "the government of Bahrain's King Hamad bin Isa al Khalifa privately told military advisors to Saudi King Abdullah bin Abdul Aziz that the 1000 man Saudi security force which entered Bahrain on March 13 should shoot to kill, if needed". ${ }^{77}$

\section{Conditions and Context}

While manipulation of identities evokes suggestions that sectarian loyalties are mobilised out of affinity with co-religious groups across the region, the largely reactive nature of engagement in proxy conflicts across the region suggests that shared identities were mobilised for other purposes. One must also question the extent to which proxy actors exercise their agency, or the extent to which external actors exert control over their proxies. A range of other factors feed into these calculations, including economics and the strength of national affinity. The case of Hizballah perhaps best illustrates this, where the group has evolved from an Iranian proxy to become an increasingly autonomous actor, as seen in the 2006 war with Israel, which many believe was conducted without a green light from Tehran.

The argument that Iran is manipulating Shi'a groups across the region fails to acknowledge a number of serious issues. Shi'a groups are not homogenous and differ greatly over the role of clerics within politics. Such differences can be seen in Iraq, with violent clashes between different Shi'a groups. While Ayatollah Ali Khamenei is Supreme Leader, he is not marja al taqlid and, for many, Grand Ayatollah Ali Sistani in Najaf is a more eminent cleric. ${ }^{78}$ The legacy of rivalry between Arabs and Persians must not be disregarded and while the desire to reduce the rivalry to sectarian difference has seduced many, in doing this, nationalist sentiment is all too easily disregarded.

While the external consequences of the escalating rivalry are clear, internal factors must not be disregarded. The prominence of religion in both states, along with the presence of sectarian cleavages, means that the external mobilisation of religion has internal consequences, perhaps best depicted in a cartoon from social media sites, featuring King Abdullah throwing a jihadi boomerang towards Syria. The position of

\footnotetext{
${ }^{76}$ Interviews, Bahrain, May 2013.

${ }^{77}$ Sidney Blumenthal, 'Startling Libya Developments; and UAE joining Saudi invitation of Bahrain' Hilary Clinton Email Archive (15.03.11) Available from: https://wikileaks.org/clintonemails/emailid/12697

${ }^{78}$ Simon Mabon, Saudi Arabia and Iran: Soft Power Rivalry in the Middle East (London: I.B. Tauris, 2013).
} 
Islam within Saudi Arabia serves as a source of legitimacy for the Al Saud, but it is also, as Madawi Al Rasheed suggests, a double-edged sword. ${ }^{79}$ The boomerang analogy can also be applied to sectarian politics in Saudi Arabia, with external manipulation of sectarian tensions also having an impact upon relations with the Shi'a of the Eastern Province. The Kingdom also faces a number of other serious domestic challenges that have had an impact upon foreign policy decisions since Abdullah's death in 2015. Political turmoil has increased, emerging from a number of factors, including power struggles within the ruling family and debates about succession within the context of transition to a different generation of Al Saud. ${ }^{80}$

\section{The US in the Gulf and the Gulf in the US: Speech Acts and The Audience}

While the facilitating conditions articulated above led policymakers in Riyadh to seek to securitize Iran, attempted speech acts were aimed at three different audiences. Domestically, the construction of the Saudi state along with the complex relationship between regime and ulemma means that the Iranian threat is often equated with a Shi'a threat. At a regional level, Saudi Arabia sought to securitize the Iranian threat to other Sunni Arab states, notably members of the Gulf Co-Operation Council, stressing that political instability is a consequence of Iranian interference. A biproduct of this was to push Saudi Arabia closer, albeit informally, to Israel, as a consequence of shared concerns about Iran. Internationally, Riyadh has sought to prevent the burgeoning rapprochement between Iran and the international community by stressing the threat posed by Tehran and in doing so, muting the 'trumpets of sabotage'. In doing this, Saudi officials have spoken to American counterparts - privately and publicly - in an effort to derail the diplomatic rapprochement, fearing the consequences of a resurgent Iran. American audiences transcend the official level and include a range of other actors, seeking to do two things: to suspend 'normal politics' towards Iran; and to feed into the facilitating conditions, changing perceptions and attitudes. This second aspect requires a different process but also leads to a different definition of success.

To understand the securitization process we must consider how security is constructed within the Persian Gulf, which, as Buzan and Wæver argue, is a (sub)regional security complex. ${ }^{81}$ The concept of a regional security complex suggests that regional security is constructed by the interactions of the states within a particular region, with great powers penetrating the region in an attempt to increase their own power. Regional security complexes are socially constructed in the sense that "they are contingent on the security practice of the actors" ${ }^{82}$ The idea of adjacency is a prominent feature of the regional security complex insofar as security is constructed by the practices and interpretations of those states within a

\footnotetext{
${ }^{79}$ Madawi Al Rasheed, A History of Saudi Arabia, p139

${ }^{80}$ Simon Henderson, Saudi Arabia: A Kingdom in Transition (The Washington Institute for Near East Policy, 20.05.14) Available from: https://www.washingtoninstitute.org/uploads/Documents/other/HendersonBelfer2014052 0-3.pdf accessed 28.05.14

81 Barry Buzan and Ole Wæver, p188

82 Ibid., p 48
} 
particular area. Such practices transcend conventional military security threats and can include the ideational and ideological. This approach provides important focus when considering security issues, noting the value of the regional level, whilst also demonstrating the relation between the regional and the international.

As Anoushiravan Ehteshami suggests, the Persian Gulf (sub)regional security complex is one of the most important in global politics, as a consequence of its geographic location and the extent of penetration by international actors. For Keith Smith, the Persian Gulf regional security complex possesses a strategic importance for the US like no other, ${ }^{83}$ meaning that such a narrative should have found a degree of traction. Indeed, the interaction of a number of factors, notably political economy, political stability and energy security, has placed the Gulf prominently within US national security calculations.

Whilst Washington has securitized Tehran since the revolution of 1979, the landscape in post 2003 Iraq would lead to an intensive securitization amongst 'intraGulf relations', alongside the US. ${ }^{84}$ Overnight, Iran acquired greater influence across the Middle East, ending its isolation in West Asia, providing a 'paved highway' for Tehran to spread influence and its vision of veleyat-e faqih across the Arab world. ${ }^{85}$ At this time, perceptions of Iran across the 'Arab Street' were increasingly popular, thanks in no small part to the actions of Hizballah, the Lebanese (Iranian supported) Party of God. ${ }^{86}$ Such popularity would stress the importance of securitization processes, for Saudi Arabia and also Israel.

The US has a long-standing relationship with Saudi Arabia and much more fractious relations with Iran. Concern at Iranian foreign policy, coupled with apparent nuclear aspirations would place Iran in George W. Bush's 'axis of evil'. For Bush, Iran posed a serious threat: "They've declared they want to have a nuclear weapon to destroy people [...] And that's unacceptable to the United States, and it's unacceptable to the world", ${ }^{87}$ yet under Obama, diplomacy would replace such bellicose rhetoric. Furthermore, for both the US and UK, the Persian Gulf occupies a key strategic point for operations across the Middle East and the Horn of Africa. ${ }^{88}$

Under the leadership of Obama, Saudi attempts to securitize Iran have largely failed to find traction. While the American audience may largely be receptive to Riyadh's concerns about Iran following almost 4 decades of fractious relations this has not translated into extra-ordinary action. Moreover, attempts to securitize the Iranian threat failed to derail diplomatic efforts to resolve the nuclear crisis, resulting in a

\footnotetext{
${ }^{83}$ Keith Smith, 'Realist Foreign Policy Analysis with a Twist: The Persian Gulf Security Complex and the Rise and Fall of Dual Containment', Foreign Policy Analysis (2014), 1-19.

${ }^{84}$ Ehteshami, p21

85 Ehetshami, p40

${ }^{86}$ Mabon, The Circle Of Bare Life

${ }^{87}$ Robin Wright, Iran a Nuclear Threat, Bush Insists (The Washington Post, 21.03.08)

Available from: http://www.washingtonpost.com/wpdyn/content/article/2008/03/20/AR2008032002284.html accessed 21.03.16

${ }^{88}$ Interview with British officials, Manama, 2013.
} 
diplomatic agreement between Iran and the P5+1 in late 2015. Israel has also attempted to speak to American audiences about Iran and to securitize the Iranian nuclear aspirations. On Holocaust Remembrance Day in 2012, Prime Minister Benjamin Netanyahu stressed that "a nuclear armed Iran is an existential threat to the state of Israel." ${ }^{\prime 9}$ To this end, Netanyahu positioned the nuclear question as an existential threat and called for the US to suspend normal politics - going beyond sanctions - to launch military strikes on Iran.

Netanyahu also spoke to Congress, where he argued that "Iran's regime poses a grave threat, not only to Israel, but also the peace of the entire world", 90 reminding Congress of their global responsibilities. The powerful AIPAC lobby would also feed into this narrative, calling for US officials to reject the nuclear deal, which would lay the groundwork for Saudi Arabia's attempted securitization. Ultimately, Netanyahu referred to the Iran deal as an "historic mistake" and the failure to convince Obama to undertake this task would feed into a rift between the two men. ${ }^{91}$ Such Israeli efforts laid the foundations for Saudi efforts, facilitating the cultivation of strong anti-Iranian sentiment within the Trump administration, particularly witnessed in the rhetoric of President Trump and the short-lived National Security Advisor, Michael Flynn.

Gulf states - led by Saudi Arabia - have sought to influence policy making in a similar manner to that achieved by AIPAC, while also seeking to maintain the support of the US. Indeed, they have often used similar messages when considering the threat posed by Iran. As a consequence, anti-Iranian sentiment is rife amongst policy makers in Washington, as demonstrated by the standing ovations received by Netanyahu upon his visits to Congress. Max Fisher suggests that Washington's position in the Middle East is to support the status quo and in the Gulf, this means continued support for Saudi Arabia. ${ }^{92}$ In an effort to ensure the continuation of this policy, Gulf States have begun to fund think tanks across Washington, under the impression that funding think tanks and universities serves as a cheaper and more successful way of cultivating a positive image and silencing potentially critical voices than using a PR firm. In doing this, Saudi efforts to securitize Iran, although unsuccessful in terms of suspending 'normal politics', have created the bi-product of feeding into anti-Iranian sentiment across policy circles and particularly within the Trump administration. Yet increased criticism of Riyadh's domestic and foreign policies, particularly on normative grounds, would make this increasingly difficult and cause problems for Washington's efforts to maintain cordial relations with Riyadh, particularly after the emergence of Da'ish.

\footnotetext{
${ }^{89}$ Benjamin Netanyahu, Holocaust Remembrance Day Address (Times of Israel, 18.04.12) Available from: http://www.timesofisrael.com

90 Full transcript of Netanyahu's address to Congress (Haaretz, 03.03.15) Available from: http://www.haaretz.com/israel-news/1.645185

91 Shibley Telhami, Netanyahu steered U.S. toward war with Iran - the result is a deal he hates (Reuters, 21.07.15) available from: http://blogs.reuters.com/great-debate/2015/07/20/the-realcredit-for-the-iran-deal-goes-to-israels-benjamin-netanyahu/

${ }^{92}$ Max Fisher, How Saudi Arabia captured Washington (Vox, 21.03.16) Available from: http://www.vox.com/2016/3/21/11275354/saudi-arabia-gulf-washington accessed 21.03.16
} 
Despite these efforts, in a 2016 article discussing his foreign policy legacy in The Atlantic, Obama expressed frustration at "free riders [who] aggravate me" in response to a discussion about some European and Gulf states who, despite expressing humanitarian concerns, were reluctant "to put skin in the game". ${ }^{93}$ Obama also suggested that regional security calculations across the Gulf would need to be recalibrated:

The competition between the Saudis and the Iranians - which has helped to feed proxy wars and chaos in Syria and Iraq and Yemen - requires us to say to our friends as well as to the Iranians that they need to find an effective way to share the neighborhood and institute some sort of cold peace. ${ }^{94}$

In a response published by Arab News, Prince Turki al Saud rejected the accusation of free riding. The article questions to what extent the pivot to Iran has resulted in equating

the Kingdom's 80 years of constant friendship with America to an Iranian leadership that continues to describe America as the biggest enemy, that continues to arm, fund and support sectarian militias in the Arab and Muslim world, that continues to harbor and host Al-Qaeda leaders, that continues to prevent the election of a Lebanese president through Hezbollah, which is identified by your government as a terrorist organization, that continues to kill the Syrian Arab people in league with Bashar Assad? $?^{95}$

This was not the first instance of prominent Saudi officials speaking to American audiences in public. In early January 2016, spurred on by recent events, a spiral of rhetoric began once more as the foreign ministers of Iran and Saudi Arabia had opinion pieces published in The New York Times and regional allies continued this strategy. Each piece sought to posit the other as a belligerent actor seeking to destabilise the region. The publication of such pieces, along with efforts to blame the other for American deaths in either 9/11 or Iraq, highlights efforts to speak to an American audience.

For Adel bin Ahmed Al Jubeir the Saudi Foreign Minister seen by many to be the protector of Sunni Muslims, Iran was responsible for regional upheaval and sought to "obscure its dangerous sectarian and expansionist policies, as well as its support for terrorism, by leveling unsubstantiated charges against the Kingdom of Saudi Arabia". ${ }^{96}$ Al Jubeir also argued that Iran is "the single-most-belligerent-actor in the region, and its actions display both a commitment to regional hegemony and a

\footnotetext{
${ }^{93}$ Jeffrey Goldberg, The Obama Doctrine, (The Atlantic) http://www.theatlantic.com/magazine/archive/2016/04/the-obama-doctrine/471525/\#5 accessed 21.03.16 
deeply held view that conciliatory gestures signal weakness either on Iran's part or on the part of its adversaries". ${ }^{97}$ The spiralling rhetoric also drew in regional allies, with the Bahraini ambassador to the UK, Fawaz bin Mohammed Al Khalifa, placing the threat posed by Shi'a militias - supported by Iran - before that posed by Da'ish, in a departure from Washington. Al Khalifa also warned against the "expansionist ambitions of the Persian Shia establishment", who are responsible for unrest in Bahrain, Lebanon, Kuwait and Yemen.

Despite these calls, the appetite to suspend normal politics and implement emergency measures was limited, making Riyadh's efforts to securitize the Iranian threat futile. Although frosty, relations between Washington and Tehran continued but the nuclear deal would provide the possibility of an improvement in relations between the two. In that sense, as there was no strike by US forces on targets in Iran, it is easy to say that securitization efforts failed. Of course, there are myriad reasons for the lack of a US strike, but Saudi securitization efforts added to antiIranian sentiment across Washington.

Such efforts did not occur without pushback from the Obama administration. In The Atlantic article, Obama also suggested that Saudi Arabia would have to learn to 'share' the Middle East with Iran, reflecting a long-standing frustration towards Saudi Arabia that can be traced back to 2002, when he spoke of the need to prevent the Kingdom and Egypt from repressing domestic populations. Of course, Obama's predilection for diplomacy over the use of force has fed into the failure of the securitization project and, if there had been a different president and administration in Washington then the process may have found a greater deal of traction, particularly with the Trump administration.

Moreover, although there is a failure to securitize Iran to the US, it is worth considering the broader impact of such a securitization process across different levels of analysis, within the context of diplomatic relations. Such a public process of securitization and attempt to suspend normal politics will have broader consequences in terms of intended and unintended audiences. Given the public nature of parts of this process, others will witness it and as such, the securitization process within the diplomatic realm may have unintended consequences and lead to securitization of the Iranian threat to other actors, or, to feed into the securitization processes that have already taken place. There are, of course, strong implications for the (sub)regional security complex in the Persian Gulf - and across the Middle East in terms of the alignment of states against Iran. Whilst regional security complexes note how the international penetrates the regional, this approach, however, stresses how the regional seeks to involve the international within the regional security complex. Such a conclusion requires greater theoretical engagement.

\footnotetext{
${ }^{97}$ Al-Jubeir, (2016).
} 


\section{Conclusions}

As this article has shown, Saudi attempts to securitize Iran to an American audience have been multifaceted and can be traced back to the 2003 invasion of Iraq. US efforts to securitize the Iranian threat can be traced back to 1979 and, when coupled with Israeli efforts to securitize Iran, Saudi efforts were well received. Initially, the securitization process occurred privately between high-ranking representatives from both sides but over time the securitization has moved from the private to the public, demonstrating perceptions of the increased severity of the Iranian 'threat'. Riyadh's failure to get Washington to suspend normal politics resulted in a more pro-active Saudi foreign policy. Such efforts did, however, contribute to anti-Iranian sentiment in Washington, feeding into the Trump administration's foreign policy and policy towards Iran and the nuclear deal. On his first official foreign visit, Trump visited Saudi Arabia, where he signed an arms deal worth approximately $\$ 500$ billion. When coupled with Trump's anti-Iranian rhetoric, many across the Kingdom were reassured that Washington was committed to ensuring that Saudi security concerns were assuaged in the coming years.

There are a number of conceptual problems with the process of securitization, in particular, the concept of the audience. This article has sought to contribute to debates surrounding the nature of the audience, particularly so, given that the securitization process was undertaken for an external audience. The decision not to suspend normal politics with Iran suggests that the securitization process failed to find traction in the US. The success of diplomatic efforts with Tehran across 2015 would make securitization efforts even more problematic. Such complexities clearly stress the need to move beyond the 'Westphalian straitjacket' within the securitization process and, ultimately, to transcend the Realist analysis that has dominated the study of the region. The melange of identities operating within - and across - state borders, coupled with the power of ideologies means that securitization efforts have a clear impact upon regional politics. Moreover, when facilitating conditions are constructed in a particular way, the securitization process has an impact upon actors and audiences across the region.

To understand the increased severity of the Iranian threat to Saudi Arabia one must examine the evolution and fracturing of political organisation across the Middle East, which has provided opportunities for actors to seek to manipulate events in their favour. With the fragmentation of the regional order, the imposition of top down narratives to shape low politics is an increasingly common feature of regional dynamics. The construction of narratives and framing of issues through a particular lens, while not new, is increasingly occurring in an attempt to construct power relations to ensure regime survival and the pursuit of geopolitical agendas.

The impact of the rivalry between Saudi Arabia and Iran upon regional security is undeniable, yet a range of other factors has increased the intensity of the rivalry. As diplomatic efforts try to resolve the civil war in Syria, the rivalry lurks ominously as it will when the international community's attention belatedly turns to Yemen. Saudi efforts to securitize the Iranian threat will only serve to make the resolution of crises 
increasingly difficult and Obama's refusal to suspend normal politics will impact upon Saudi relations with the US. What is irrefutable, however, is that the people of the region are paying the heaviest price. 